\title{
Effects of Melatonin upon Vascularity of Cartilage End Plate of Intervertebral Disc
}

\section{Yigit Uyanıkgil'1,2, Emel Oykü Cetin ${ }^{3}$ and Mehmet Turgut ${ }^{4 *}$}

${ }^{1}$ Department of Histology and Embryology, Ege University, School of Medicine, Izmir, Turkey

${ }^{2}$ Cord Blood, Cell-Tissue Research and Application Center, Ege University, Izmir, Turkey

${ }^{3}$ Department of Pharmaceutical Technology, Biopharmaceutics and Pharmacokinetics, Ege University, Faculty of Pharmacy, Izmir, Turkey

${ }^{4}$ Department of Neurosurgery, Adnan Menderes University, School of Medicine, Aydın, Turkey

\section{Editorial}

Anatomically, intervertebral disc (IVD) consists of three part; nucleus pulposus, annulus fibrosus and cartilage end plate (CEP) at the cranial and caudal vertebral interface of the disc $[1,2]$. In both animals and humans, the IVD consists largely of extracellular matrix with a low cell density. In many respects, that degeneration and age- related changes are characterised by biochemical and structural changes components of the IVD $[1,3]$.

On the other hand, melatonin (MEL) is a secretory product synthesized by the pineal gland. It is formulated with N-acetyl-5methoxytryptamine. MEL has a scavenger effect on hydroxyl and peroxyl molecules and may have anti-ageing properties due to its antioxidant nature [4,5]. During the last decade, some authors suggested that pineal neurohormone MEL has various effects upon some bone markers and osteoblast differentiation in relation to aging [6-8]. Neverteheless, the mechanism of the effect of MEL on trabecular width ligament thickness and degenerated IVD tissue are not clear to date [6]. Roth et al. [7] reported that MEL, applied in micromolar concentrations, was a mitogen for bone tissues. It has been suggested that MEL promotes osteoblast differentiation and matrix mineralisation via transmembrane receptors and regulates bone remodelling $[7,8]$. Turgut et al. [9] reported that MEL was applied as a treatment to the created degenerative effects of surgery on CEP and exogenous MEL significantly increased vascularization on trabecular reduction in width, suggesting its regenerative effects in IVD tissue degeneration.

Consequently, it is certain that further experiments and randomized controlled clinical studies should be done for standardization of the clinical use of MEL upon the vascularity of CEP of IVD. However, we strongly hope that future search will confirm the useful effects of novel drug MEL treatment as a biological anti-ageing agent to treating IVD degeneration.

\section{References}

1. Alini M, Roughley PJ, Antoniou J, Stoll T, Aebi M (2002) A biological approach to treating disc degeneration: not for today, but maybe for tomorrow. Eur Spine J 2: S215-220.

2. Moore RJ (2000) The vertebral end-plate: what do we know?. Eur Spine J 9 92-96.

3. Reiter RJ (1995) The pineal gland and melatonin in relation to aging: a summary of the theories and of the data. Exp Gerontol 30: 199-212.

4. Turgut M, Uslu S, Uysal A, Yurtseven ME, Ustün H (2003) Changes in vascularity of cartilage endplate of degenerated intervertebral discs in response to melatonin administration in rats. Neurosurg Rev 26: 133-138.

5. Kabuto H, Yokoi I, Ogawa N (1998) Melatonin inhibits iron-induced epileptic discharges in rats by suppressing peroxidation. Epilepsia 39: 237-243.

6. Bizzarri M, Cucina A, Valente MG, Tagliaferri F, Borrelli V, et al. (2003) Melatonin and vitamin D3 increase TGF-beta1 release and induce growth inhibition in breast cancer cell cultures. J Surg Res 110: 332-337.

7. Roth JA, Kim BG, Lin WL, Cho MI (1999) Melatonin promotes osteoblast differentiation and bone formation. J Biol Chem 274: 22041-22047.

8. Ostrowska Z, Kos-Kudla B, Swietochowska E, Marek B, Kajdaniuk D, et al. (2001) Assessment of the relationship between dynamic pattern of nighttime levels of melatonin and chosen biochemical markers of bone metabolism in a rat model of postmenopausal osteoporosis. Neuro Endocrinol Lett 22: 129-136.

9. Turgut M, Oktem G, Uslu S, Yurtseven ME, Aktuğ H, et al. (2006) The effect of exogenous melatonin administration on trabecular width, ligament thickness and TGF-beta(1) expression in degenerated intervertebral disk tissue in the rat. J Clin Neurosci 13: 357-363.
*Corresponding author: Mehmet Turgut, M.D., PhD, Cumhuriyet Mahallesi, Adnan Menderes Bulvarı, Haltur Apartmanı No: 6/7, 09020 Aydın, Turkey, Tel: +90 256 2134874; Fax: +90. 256.2120146; E-mail: drmturgut@yahoo.com

Received April 03, 2016; Accepted April 05, 2016; Published April 07, 2016

Citation: Uyanıkgil Y, Cetin EO, Turgut M (2016) Effects of Melatonin upon Vascularity of Cartilage End Plate of Intervertebral Disc. J Spine 5: e123. doi:10.4172/2165-7939.1000e123

Copyright: (c) 2016 Uyanıkgil $\mathrm{Y}$, et al. This is an open-access article distributed under the terms of the Creative Commons Attribution License, which permits unrestricted use, distribution, and reproduction in any medium, provided the original author and source are credited. 